\title{
Em memória do Professor Carlos Moutinho
}

\author{
https://doi.org/10.5628/rpcd.04.01.113
}

Recordar alguém é assumir a justiça da celebração que devemos àqueles que estiveram ligados a nós e que deixam um rasto indestrutível de recordações que persistirão, indeléveis, nas nossas memórias.

É com este sentimento que invocamos, neste espaço, o nosso amigo e companheiro de viagem, o qual nos deixou, sem aviso, recentemente. Infelizmente a sua auspiciosa carreira foi abruptamente interrompida aos 47 anos de idade, coarctando-lhe o desenvolvimento de potencialidades pessoais e profissionais emergentes.

Escrever sobre Carlos Moutinho é, incontornavelmente, escrever de Voleibol porquanto a sua dedicação em prol do desenvolvimento da modalidade constituía uma das suas primeiras prioridades, a qual o fazia mover "montanhas", consertando divergências em torno de ideais comuns.

No seu percurso é notória a preocupação em aliar o conhecimento do académico ao do treinador, sempre no sentido de criar alicerces teóricos capazes de sustentar as suas convicções, decorrentes de uma prática reflectida, sistemática e duradoira. Disso são testemunho os 20 anos como treinador durante os quais lhes associou a carreira académica, mantendo-a invariavelmente ligada ao treino.

A sua intervenção enquanto treinador foi rica e diversificada, tanto ao nível dos propósitos da prática como dos contextos afins, estendendo-se da formação ao alto rendimento, da actividade nos clubes às selecções nacionais. Alcança por diferentes ocasiões títulos nacionais e honra a selecção nacional de juniores masculinos por diferentes ocasiões, tanto em torneios internacionais como em campeonatos, como é o caso do título da FISEC em 1988, na Bélgica.

Em 1989 inicia a sua carreira académica no Instituto Superior de Educação Física do Porto fazendo parte do Gabinete de Voleibol. A sua experiência como treinador e a sua avidez pelo conhecimento fazem-no, desde cedo, situar a actividade de investigação na problemática da análise do jogo, sendo um dos pioneiros desta área, aflorada nas provas de aptidão pedagógica e de capacidade científica em 1993 e aprofundada no doutoramento em 1998.
Sempre com o interesse genuíno de dotar o Voleibol de conhecimentos concorrentes de uma abordagem progressivamente mais científica, esforça-se por dotar a observação do jogo em situação real de competição de maior rigor, objectividade e profundidade. Assume a função de supervisor na análise e avaliação do jogo da Federação Internacional de Voleibol em 1996 e é indigitado para a coordenação da área da estatística do jogo em diferentes competições de relevo internacional, ao mesmo tempo que se torna membro da sociedade científica internacional Notational Analysis of Sport.

O reconhecido mérito que lhe é atribuído pelas entidades federativas e associativas do Voleibol Nacional e Internacional estende-se ao domínio da formação de treinadores. Integra o corpo de prelectores da Federação Portuguesa de Voleibol em 1998, sendo presença assídua como prelector nos diferentes níveis dos cursos de treinadores de Voleibol. Simultaneamente, assume as funções de Director nos cursos de nível III da Federação Portuguesa de Voleibol (curso de maior relevo nacional) e do curso de nível I da Associação de Voleibol do Porto.

A sua dedicação e competência extravasa fronteiras e, em 1998, é nomeado Instrutor da Federação Internacional de Voleibol. O seu espírito empreendedor e de aventura leva-o a aceitar um desafio ímpar proposto pela Federação Internacional de Voleibol e Comité Olímpico Internacional: levar o Voleibol a terras longínquas de língua portuguesa. Em Agosto e Setembro de 1998, o nosso colega, sempre movido pela sua grande paixão, enceta uma viagem por África, percorrendo a República Popular de Angola, a República Popular de Moçambique, S. Tomé e Príncipe e, finalmente, Cabo Verde, na realização de cursos para professores e treinadores da modalidade. Dessa viagem exaltou sempre, com nostalgia e saudade, as experiências vividas, a humildade, a franqueza e perseverança de povos irmãos que perante condições tão precárias de existência deixavam perceber a vontade imensurável de aprender. Esta odisseia deixou, sem sombra de dúvida, uma marca indelével na sua existência, expressão viva da sua humanidade. 
Não seria justo determo-nos mais sobre estas facetas sob pena de incorrermos no risco de negligenciar outras, não menos importantes. Referimo-nos à sua actividade enquanto dirigente associativo. A sua vontade de evoluir, de fazer parte das grandes decisões, de questionar o que tacitamente é aceite pela maioria, movem-no para o mundo associativo. Inconformado com o status quo envolve-se, desde muito jovem, nos movimentos associativos académicos sustentado pela sua vocação de líder. Em tempos tempestuosos e naufragantes do Instituto Superior de Educação Física da Universidade do Porto, corria o ano de 1982, é eleito Presidente da Associação de Estudantes.

Todavia, a inquietude perante as políticas desportivas vigentes não se extingue com o avançar da idade, agudiza-se, bem pelo contrário, tendo expressão particular na defesa convicta e consistente dos treinadores, enquanto classe a legitimar. Sabendo que ser treinador reveste-se de um estatuto precário e de linhas indefinidas no panorama do Desporto Nacional, motivado pelas suas crenças, valores e conhecimentos, faz despertar a preocupação dos treinadores portugueses em conferir dignidade, estatuto e reconhecimento social à profissão.

Foi o olhar posto no futuro que lhe permitiu atrever-se a agir. Uma grande esperança que num curto espaço de tempo começou a tornar-se realidade através da coordenação da comissão pré-eleitoral da Associação Nacional de Treinadores de Voleibol, em 1998. Num esforço de congregar forças, suportado pelo elevado espírito de diálogo, assume a presidência da Associação Nacional de Treinadores de Voleibol ainda no mesmo ano, assistindo-se, desde então, a um reconhecimento progressivo das instituições e entidades afectas à modalidade e ao reforço da participação dos treinadores na definição de estratégias de desenvolvimento, com raízes para proliferar no futuro. O seu horizonte passava, indubitavelmente, pela paridade dos treinadores nos diferentes domínios de intervenção desportiva, expressa numa voz activa, participativa e actuante. O seu envolvimento, esforço e dedicação merecem, no mínimo, de todos nós a responsabilidade de não desmoronar, fazendo-se justiça ao seu empenho e dedicação.

Toda esta escalada foi acompanhada da actividade académica, tanto no âmbito da docência como da investigação. O domínio da docência foi marcadamente dirigido para as disciplinas afectas ao desporto de rendimento no Voleibol, tanto na Licenciatura como no Mestrado de Alto Rendimento. No âmbito da investigação, a busca de novos conhecimentos, paradigmas e teorias, teve sempre como meta o Voleibol. Ciente de que o Voleibol não é ciência, mas sabendo que esta, por lidar com pro- blemas, e na busca de soluções para eles, faz emergir novos conhecimentos e novos problemas, dedicou particular atenção aos ditames científicos que robusteciam o desenvolvimento do Voleibol. A modelação do jogo, bem como a análise da actividade do jogador em competição, constituíram as temáticas que lhe foram particularmente queridas. Este particular interesse sustentava-se na convicção de que só com um entendimento substantivo, fundamentado em metodologias de análise e observação cientificamente válidas, é possível aceder a um conhecimento simultaneamente profundo e abrangente do jogo e do rendimento das equipas. A sua actividade científica foi suportada por mais de 50 publicações e por mais de 70 comunicações em congressos, simpósios e reuniões técnico-profissionais.

Conciliar o inconciliável, encontrar o equilíbrio em pontos de conflito e divergências, servir os interesses de muitos em prol do desenvolvimento do Desporto implica atenção, persistência, teimosia e ousadia. Todos estes epítetos assentavam cabalmente ao nosso colega Moutinho.

O legado herdado não pode ser esquecido nem tam-pouco ignorado. O esforço de valorização profissional da carreira dos treinadores de Voleibol portugueses e a vontade de abrir fronteiras, de desbravar caminhos no sentido de dotar o Voleibol de um suporte científico, no vislumbrar de novos horizontes de evolução, foram, inequivocamente, os motivos primeiros do seu ânimo profissional. Este esforço teve a sua grande expressão no livro "A Investigação em Voleibol - Estudos Ibéricos", publicação da nossa Faculdade. Felizmente que ainda lhe foi permitido assistir ao seu nascimento. O orgulho e satisfação pela obra concebida foi bem visível no momento em que o afagou pela primeira vez entre mãos. A ele o dedicamos por inteiro.

A incontornável efemeridade da vida faz-nos sentir com tristeza e saudade a sua ausência. A proximidade temporal do seu falecimento não nos permite expressar por palavras o que nos mói e magoa no mundo dos sentidos. Todavia, convictamente acreditamos que apesar da vida lhe ter sido fugidia, a extensa actividade profissional, valorizada por um envolvimento pessoal marcante, vivifica a sua perda, sustentáculo da sua memória.

\section{Isabel Mesquita}

Coordenadora do Gabinete de Voleibol

Faculdade de Ciências do Desporto e de Educação Física Universidade do Porto 